\title{
Pollen morphology of some species of Buddleja L. (Buddlejaceae) from North-east India and its taxonomic significance
}

\author{
Suchandrima Siddhanta, Subir Bera and Debabrata Maity ${ }^{1}$ \\ Department of Botany, University of Calcutta, 35 Ballygunge Circular Road, Kolkata - 700 019, \\ West Bengal, India \\ ${ }^{1}$ Corresponding author; e-mail: debmaity@yahoo.com
}

[Received 17.11.2018; Revised 18.12.2018; Accepted 19.12.2018; Published 31.12.2018]

\begin{abstract}
Pollen grains of five species of Buddleja L. (Buddlejaceae), collected from North-east India have been examined thoroughly both by Light Microscopy (LM) and Scanning Electron Microscopy (SEM). On the basis of number of pollen apertures, the species are divided into two basic types, viz., Type I: 4-5-colporate grains and Type II: 3-colporate grains. Differentiation of the individual species has been done on the basis of critical differences of micromorphological characters of pollen aperture and exine stratification/ornamentation. The interspecies heteromorphism of pollen features are used to recognize the studied species. The taxonomic significance of these characters is discussed. Finally, an artificial key has been constructed for easy and correct identification of the taxa studied.
\end{abstract}

Key words: Buddleja L., North-east India, Pollen characters, Taxonomic significance

\section{INTRODUCTION}

Buddleja L. (Buddlejaceae), commonly known as the butterfly bush, is a genus comprising of about 90 species in the world, endemic to tropics and subtropics of America, Africa, and Asia, especially in South-east Asia (Mabberley 2017). In India, the genus is represented by 11 species (Santapau \& Henry 1973). Rich concentration of the wild inhabitants (ca. 8 species) is found in the North-eastern states of the country, viz, Arunachal Pradesh, Meghalaya, Mizoram, Nagaland, Sikkim and Darjeeling Hills of West Bengal (C. B. Clarke 1883; Das \&

Table 1. Distribution of Buddleja species in NE India

\begin{tabular}{|l|l|l|l|}
\hline \multicolumn{1}{|c|}{ Name of Species } & \multicolumn{1}{|c|}{$\begin{array}{c}\text { Distribution in } \\
\text { India }\end{array}$} & \multicolumn{1}{|c|}{ Places of collection } & \multicolumn{1}{c|}{ Collection number } \\
\hline Buddleja asiatica Lour. & $\begin{array}{l}\text { Almost throughout } \\
\text { India }\end{array}$ & $\begin{array}{l}\text { West Bengal (Darjeeling), } \\
\text { Sikkim }\end{array}$ & $\begin{array}{l}\text { Siddhanta \& Maity 303, } \\
\text { 305, Siddhanta 338 }\end{array}$ \\
\hline $\begin{array}{l}\text { Buddleja colvilei Hook.f. } \\
\text { \& Thomson }\end{array}$ & $\begin{array}{l}\text { NE India (including } \\
\text { Darjeeling) }\end{array}$ & Sikkim & Maity 20231 \\
\hline Buddleja crispa Benth. & $\begin{array}{l}\text { NE India } \\
\text { (cultivated) }\end{array}$ & Arunachal Pradesh & Siddhanta \& Bera 312 \\
\hline $\begin{array}{l}\text { Buddleja macrostachya } \\
\text { Wall. ex Benth. }\end{array}$ & $\begin{array}{l}\text { NE India (including } \\
\text { Darjeeling) }\end{array}$ & $\begin{array}{l}\text { Arunachal Pradesh, } \\
\text { Meghalaya, Sikkim }\end{array}$ & $\begin{array}{l}\text { Siddhanta \& Bera 315, } \\
316\end{array}$ \\
\hline $\begin{array}{l}\text { Buddleja paniculata } \\
\text { Wall. ex Roxb. }\end{array}$ & $\begin{array}{l}\text { NE India (including } \\
\text { Darjeeling) }\end{array}$ & $\begin{array}{l}\text { Arunachal Pradesh, } \\
\text { Manipur }\end{array}$ & $\begin{array}{l}\text { Siddhanta \& Bera 349, } \\
\text { Bera } 126\end{array}$ \\
\hline
\end{tabular}


Chanda 1987; Chowdhery 2008; Murmu 2016; Dash \& Singh 2017; Maity et al. 2018). Present investigation deals with five species of the genus occurring in North-east India of which only B. crispa is a common garden plant and others are wild (Table 1). All these four wild species are also recorded from Darjeeling and Terai regions of West Bengal (Murmu 2016). Das \& Chanda (1987) recorded B. asiatica, B. davidii, B. paniculata from the temperate hills of Darjeeling.

The species of Buddleja are morphologically well characterized, however, only few fragmentary works on pollen morphology of the genus is available globally (Erdtman 1952; Punt \& Leenhouts, 1967; Mosyakin \& Tsymbalyuk 2013). Long back, Wilhelm (1910) used pollen characters of Buddlejaceae for separating the genus from rest of the members of the family. Notably, in India pollen characterization or a suitable key to the species for classifying the genus on the basis of pollen features is not yet being reported inspite of its abundance in the North eastern states. Furthermore, B. asiatica is abundant in Darjeeling hills and TeraiDuars and B.paniculata is quite common in Darjeeling hills and is frequent in Duars.

Present study deals with detailed investigation of the palynomorphs of the five species of North-east Indian Buddleja out of eight species known to occur in this region (Clarke 1883; Das \& Chanda 1987; Li \& Leeuwenberg 1996; Chowdhery 2008; Murmu 2016; Dash $\&$ Singh 2017; Maity et al. 2018). Pollen grains were studied through evaluation of overall shape and size, nature and number of apertures, detail aperture characteristics and exine wall stratification. All these characters are used in detail characterization as well in grouping of the taxa. Furthermore, Pollen load count of individual anther and pollen viability percentage of each species are also provided. An artificial key is prepared for easy and correct identification of the species.

\section{MATERIALS AND METHODS}

Mature flower buds and immature flowers of the five studied species of Buddleja were collected from different parts of Arunachal Pradesh, Meghalaya, Manipur, West Bengal (Darjeeling) and Sikkim. All the species were properly identified with the help of relevant literature (Clarke 1883; Li \& Leeuwenberg 1996; Rae 2001; Chowdhery 2008; Murmu 2016; Dash \& Singh 2017). The pollen grains were properly acetolyzed following standard methodology (Erdtman 1960) and prepared for light microscopy (LM) and scanning electron microscopy (SEM). Pollen Load Count (PLC) from the anthers was also recorded using haemocytometer (Kearns \& Inonye 1993). Pollen viability percentage (PV) of each species was calculated following Norton (1966).

\section{RESULT}

\section{Buddleja asiatica Lour., Fl. Cochinch. 1: 72. 1790. [Figure 1A,B,C]}

Pollen grains monads, homomorphic, tricolporate, prolate-spheroidal to sub-prolate, 15.6-18 $\mu \mathrm{m} \times 12-15 \mu \mathrm{m}$ in equatorial view, $12-18 \mu \mathrm{m} \times 9-15 \mu \mathrm{m}$ in polar view; colpi $12-15 \mu \mathrm{m}$ long, homomorphic, membranes psilate, margins rugose; endocolpi psilate; apocolpium present; ora lalongate about $3.2 \mu \mathrm{m}$ diam; amb angular, goniotreme, about $3 \mu \mathrm{m}$ diam; exine psilate with microperforations; exine thicker than intine, exine and intine $4.4 \mu \mathrm{m}$ and $0.6 \mu \mathrm{m}$ thick respectively; tectate, tectum perforated, baculae indistinct.

$\begin{array}{lll}\text { NPC number } & : & 345 \\ \text { PLC } & : & 3,666 \text { (approx.) } \\ \text { PV } & : & 72.80 \%\end{array}$



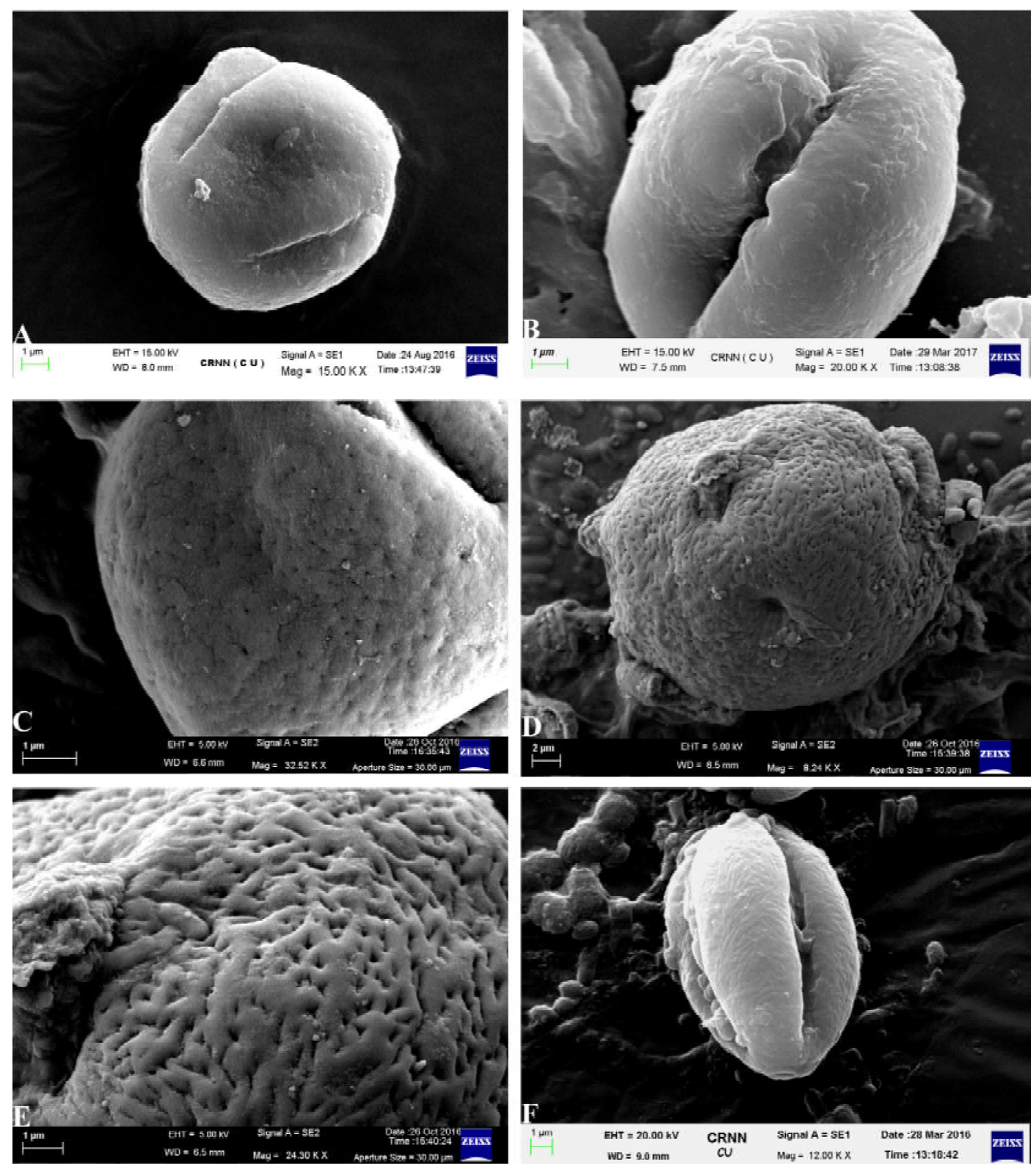

Figure 1: Details of pollen grains of studied Buddleja species: A - C. B.asiatica; D \& E. B. colvilei; F. B. crispa.

\section{Buddleja colvilei Hook.f., Ill. Himal. Pl. t. 18. 1855. [Figure 1D,E]}

Pollen grains monads, heteromorphic, pentacolporate, prolate-spheroidal, 27.9-30 $\mu \mathrm{m}$ x 26.7$27 \mu \mathrm{m}$ in equatorial view, 27-36 $\mu \mathrm{m} \times 24-36 \mu \mathrm{m}$ in polar view; colpi heteromorphic, central colpus about $15 \mu \mathrm{m}$ long, laterals $18-21 \mu \mathrm{m}$ long respectively; colpi membranes psilate with microperforations, margins rugose; endocolpi rugose; apocolpium present; ora lalongate, heteromorphic, ora of all laterals about $5 \mu \mathrm{m}$ diam and central colpus about $5.9 \mu \mathrm{m}$ diam; amb semiangular to circular, goniotreme to peritreme, about 2-3 $\mu \mathrm{m}$ diam; exine foveolate; 
exine thicker than intine; exine and intine $4.4 \mu \mathrm{m}$ and $0.6 \mu \mathrm{m}$ thick respectively; tectate, tectum perforated, baculae indistinct.

$\begin{array}{lll}\text { NPC number } & : & 545 \\ P L C & : & 4,733 \text { (approx.) } \\ \text { PV } & : & 93.10 \%\end{array}$

Buddleja crispa Benth., Scroph. Ind. 43. 1835. [Figure 1F, 2A]

Pollen grains monads, homomorphic, tricolporate, sub-prolate, $15.9-18 \mu \mathrm{m} \times 12-15 \mu \mathrm{m}$ in equatorial view, $12-15 \mu \mathrm{m} \times 9-12 \mu \mathrm{m}$ in polar view; colpi about $13.5 \mu \mathrm{m}$ long, homomorphic, membranes rugulate, margins rugose; endocolpi psilate; apocolpium present; ora lalongate, about $3.2 \mu \mathrm{m}$ diam; amb angular, goniotreme, about $3 \mu \mathrm{m}$ diam; exine rugulate; exine thicker than intine, exine and intine about $4.4 \mu \mathrm{m}$ and $0.6 \mu \mathrm{m}$ thick respectively; tectate, tectum perforated, baculae indistinct.

$\begin{array}{lll}\text { NPC number } & : & 345 \\ P L C & : & 2,830 \text { (approx.) } \\ P V & : & 67.41 \%\end{array}$

Buddleja macrostachya Benth., Scroph. Ind. 42. 1835. [Figure 2B,C]

Pollen grains monads, heteromorphic, tetracolporate, rarely pentacolporate, prolate-spheroidal to sub-prolate, $18-24 \mu \mathrm{m} \times 15-21 \mu \mathrm{m}$ in equatorial view, $15-18.9 \mu \mathrm{m} \times 12-16.2 \mu \mathrm{m}$ in polar view; colpi heteromorphic, lateral colpi $12-13.5 \mu \mathrm{m}$ long, central colpus 12.7-15 $\mu \mathrm{m}$ long; all clopi membranes rugose with microperforations, margins rugose; endocolpi psilate; apocolpium present; ora lalongate, about $3.2 \mu \mathrm{m}$ diam; amb angular to rarely circular, goniotreme to rarely peritreme, about $3 \mu \mathrm{m}$ diam, rarely $2 \mu \mathrm{m}$ diam; exine psilate with microperforations; exine thicker than intine, exine and intine $4.7 \mu \mathrm{m}$ and $1.5 \mu \mathrm{m}$ thick respectively; tectate, tectum perforated, baculae indistinct.

$\begin{array}{lll}\text { NPC number } & : & 445, \text { rarely } 545 \\ \text { PLC } & : & 6,100 \text { (approx.) } \\ \text { PV } & : & 75.98 \%\end{array}$

Buddleja paniculata Wall. in Roxb., Fl. Ind. 1: 412. 1820. [Figure 2D,E,F]

Pollen grains monads, homomorphic, tricolporate, sub-prolate, $15-18 \mu \mathrm{m} \times 12-15.7 \mu \mathrm{m}$ in equatorial view, 12-15 $\mu \mathrm{m} \times 9-12 \mu \mathrm{m}$ in polar view; colpi 9-14.7 $\mu \mathrm{m}$ long, homomorphic, membranes psilate, margins rugose; endocolpi rugose; apocolpium present; ora lalongate, about $2.9 \mu \mathrm{m}$ diam; amb angular, goniotreme, about $3 \mu \mathrm{m}$ diam; exine psilate with microperforations; exine thicker than intine, exine and intine about $4.4 \mu \mathrm{m}$ and $0.6 \mu \mathrm{m}$ thick respectively; tectate, tectum perforated, baculae indistinct.

$\begin{array}{lll}\text { NPC number } & : & 345 \\ P L C & : & 4,605 \text { (approx.) } \\ P V & : & 86.77 \%\end{array}$

A comparison of major pollen features of the studied species of Buddleja has been represented in Table 2 . 

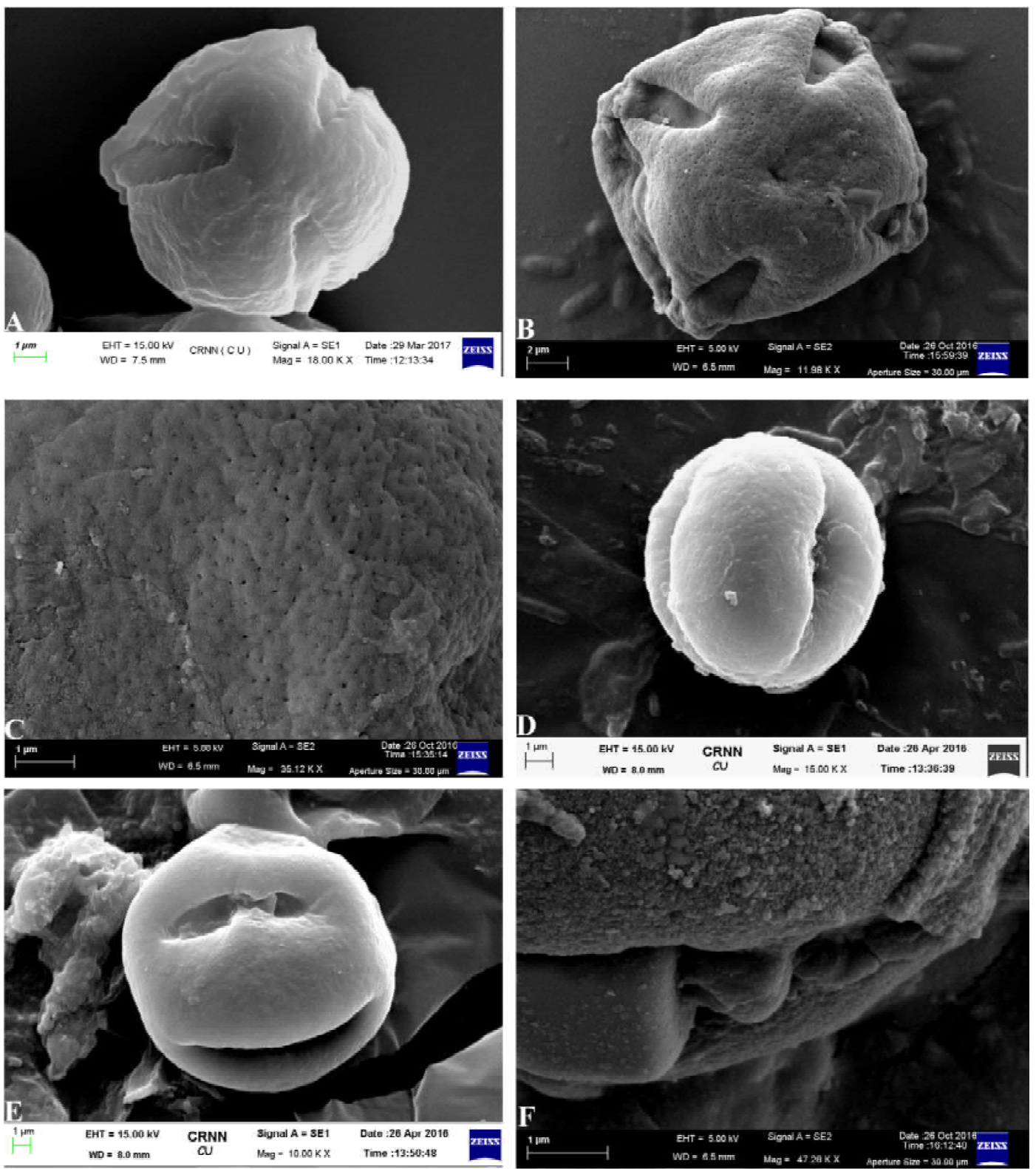

Figure 2: Details of pollen grains of studied Buddleja species: A. B. crispa; B \& C. B. macrostachya; D - F. B. paniculata

\section{DISCUSSION}

The studied species of Buddleja exhibits a wide range of variation in pollen characters. The smallest pollen grains are recorded in B. asiatica $(15-18 \mu \mathrm{m} \times 12-15 \mu \mathrm{m})$, whereas, the largest one found in B. colvilei $(27.9-30 \mu \mathrm{m} \times 26.7-27 \mu \mathrm{m})$. Among all the studied taxa of the genus, $B$. asiatica, B. crispa and B. paniculata are homomorphic and $B$. colvilei and $B$. macrostachya are with heteromorphic pollen grains. Moreover, the pollen grains of $B$. colvilei have heteromorphic colpi. Central colpus of pollen in this species 
Table 2. Comparison of major pollen features of the studied species of Buddleja L.

\begin{tabular}{|c|c|c|c|c|c|c|c|}
\hline \multirow{3}{*}{$\begin{array}{l}\text { Name of } \\
\text { species }\end{array}$} & \multicolumn{3}{|l|}{ Grains } & \multicolumn{2}{|l|}{ Colpi } & \multirow{3}{*}{$\begin{array}{l}\text { Oras } \\
\text { Nature }\end{array}$} & \multirow{3}{*}{$\begin{array}{l}\text { Pollen Sculptures } \\
\begin{array}{l}\text { Exine } \\
\text { ornamentation }\end{array}\end{array}$} \\
\hline & Size $(\mu \mathrm{m})$ & \multirow[t]{2}{*}{ Shape } & \multirow{2}{*}{$\begin{array}{l}\text { NPC } \\
\text { No. }\end{array}$} & \multirow[t]{2}{*}{ Nature } & \multirow[t]{2}{*}{ Size $(\mu \mathrm{m})$} & & \\
\hline & $\begin{array}{l}\text { Polar Axis } \\
(\mu \mathrm{m}) \times \\
\text { Equatorial } \\
\text { Diameter( } \mu \mathrm{m}) \\
\text { (Equatorial } \\
\text { view; Polar } \\
\text { view) }\end{array}$ & & & & & & \\
\hline $\begin{array}{l}\text { Buddleja } \\
\text { colvilei }\end{array}$ & $\begin{array}{l}27.9-30 \times \\
26.7-27 ; \\
27-36 \times 24-33\end{array}$ & $\begin{array}{l}\text { Prolate- } \\
\text { Spheroidal }\end{array}$ & 545 & $\begin{array}{l}\text { Hetero- } \\
\text { morphic }\end{array}$ & $\begin{array}{l}\text { Central } \\
\text { colpus about } \\
15 \text {, laterals } \\
18-21\end{array}$ & Lalongate & Foveolate \\
\hline $\begin{array}{l}\text { Buddleja } \\
\text { macrostachya }\end{array}$ & $\begin{array}{l}18-24 \times 15-21 ; \\
15-18.9 \times 12- \\
16.2\end{array}$ & $\begin{array}{l}\text { Prolate - } \\
\text { Spheroidal } \\
\text { to Sub- } \\
\text { prolate }\end{array}$ & $\begin{array}{l}445, \\
\text { rarely } \\
545\end{array}$ & $\begin{array}{l}\text { Hetero- } \\
\text { morphic }\end{array}$ & $\begin{array}{l}12.7-15 \text { in } \\
\text { laterals from } \\
\text { in central } \\
\text { colpus about } \\
12-13.5\end{array}$ & Lalongate & $\begin{array}{l}\text { Psilate with } \\
\text { microperforations }\end{array}$ \\
\hline $\begin{array}{l}\text { Buddleja } \\
\text { paniculata }\end{array}$ & $\begin{array}{l}15.6-18 \times 12- \\
15.7 \\
12-15 \times 9-12\end{array}$ & $\begin{array}{l}\text { Sub- } \\
\text { Prolate }\end{array}$ & 345 & $\begin{array}{l}\text { Homo- } \\
\text { morphic }\end{array}$ & $12-15$ & Lalongate & $\begin{array}{l}\text { Psilate with } \\
\text { microperforations }\end{array}$ \\
\hline $\begin{array}{l}\text { Buddleja } \\
\text { crispa }\end{array}$ & $\begin{array}{l}15.9-18 \times 12- \\
15 ; \\
12-15 \times 9-12\end{array}$ & $\begin{array}{l}\text { Sub - } \\
\text { Prolate }\end{array}$ & 345 & $\begin{array}{l}\text { Homo- } \\
\text { morphic }\end{array}$ & 13.5 & Lalongate & Rugulate \\
\hline $\begin{array}{l}\text { Buddleja } \\
\text { asiatica }\end{array}$ & $\begin{array}{l}15-18 \times 12-15 ; \\
12-18 \times 9-15\end{array}$ & $\begin{array}{l}\text { Prolate - } \\
\text { Spheroidal } \\
\text { to Sub- } \\
\text { prolate }\end{array}$ & 345 & $\begin{array}{l}\text { Homo- } \\
\text { morphic }\end{array}$ & $9-14.7$ & Lalongate & $\begin{array}{l}\text { Psilate with } \\
\text { microperforations }\end{array}$ \\
\hline
\end{tabular}

Table 3. Tabular representation for distinguishing the pollen types and subtypes among the species of Buddleja L. (Buddlejaceae)

\begin{tabular}{|l|l|l|}
\hline Buddleja species & Pollen type & Pollen subtype \\
\hline Buddleja colvilei & I & - \\
\hline Buddleja macrostachya & I & - \\
\hline Buddleja crispa & II & II.I \\
\hline Buddleja asiatica & II & II.II \\
\hline Buddleja paniculata & II & II.II \\
\hline
\end{tabular}

measures about $15 \mu \mathrm{m}$, laterals varies from $18-21 \mu \mathrm{m}$. B. macrostachya exhibits heteromorphism regarding its grain aperture number and size of colpi. It has dimorphic pollen. Both 4-aperturate and 5-aperturate grains are recorded in this species. Moreover, the central colpus, measuring $12-13.5 \mu \mathrm{m}$, is somehow smaller and wider than the other three laterals $(12.7-15 \mu \mathrm{m})$.

The number of aperture varies significantly in the studied members. Pollen grains in $B$. colvile $i$ are strictly 5-aperturate. B. macrostachya is with dimorphic grains with both 4and 5-apertures. In contrast, B. asiatica, B. crispa and B. paniculata are having strictly 3aperturate grains.

The shape of the pollen grains is variable in all five species. Prolate-spheroidal grains are found in B. colvile $i$ whereas in B. crispa and B. asiatica pollen grains are sub-prolate. Significantly, in other two species, viz. B. macrostachya and B. paniculata prolate-spheroidal to sub-prolate grains are recorded. 
The colpi membranes exhibit wide range of variation in these species. It is smooth in $B$. asiatica, smooth with microperforations in $B$. colvilei, rugulate in $B$. crispa, rugose with microperforations in $B$. macrostachya and smooth in $B$. paniculata. Colpi margins are without projections (costae) in all the species. The size of colpi in the species with homomorphic grains varies from $12-15 \mu \mathrm{m}$. Whereas, the heteromorphic grain bearing species like $B$. colvilei, the second colpus is shortest and widest $(15 \mu \mathrm{m})$ than the other four (laterals 18 $21 \mu \mathrm{m})$. The other species with heteromorphic pollen grains $B$. macrostachya, the central colpus is a bit shorter and wider $(12-13.5 \mu \mathrm{m})$ than the rest three laterals $(12.7-15 \mu \mathrm{m})$. Ora is lalongate in all the studied species.

The exine stratification spectrum in the studied species is impressive. Exine ornamentation varies from foveolate $(B$. colvilei), rugulate (B. crispa) to psilate with microperforations (B. asiatica, B. macrostachya and B. paniculata) and these features are important towards the correct identification of species as well as in grouping of the species. This heteromorphism in pollen structure, both qualitative as well as quantitative, have great taxonomic significance towards correct identity of the species.

Based on this observation, the pollen grains of the studied taxa have been divided into two basic types (Table 3). Type I is characterized by $4-5$-aperturate grains (B. colvilei and

Key to the studied species of Buddleja $\mathbf{L}$.

1a. Grains 3-aperturate....................................................... 2

1b. Grains 4-5-aperturate.................................................. 4

2a. Exine rugulate............................................................. B.

2b. Exine psilate ............................................................ 3

3a. Length of colpi 9-14.7 ìm................................................. B. asiatica

3b. Length of colpi 12-15 ìm................................................. B. paniculata

4a. Grains 4-aperturate, exine psilate......................................... B. macrostachya

4b. Grains 5-aperturate, exine foveolate...................................... B. colvilei

\section{Acknowledgements}

Ministry of Environment, Forest and Climate Change, Government of India is thanked for financial assistance. Authors thank the UGC-CAS Phase VII, Department of Botany, University of Calcutta for providing necessary facilities. They are thankful to Department of Forests, Environment and Wildlife Management, Govt. of Sikkim, Forest Department of Arunachal Pradesh, Meghalaya, Manipur and West Bengal for permitting our field visit. Also, they are grateful to Prof. A. P. Das, Visiting Professor, Rajiv Gandhi University for his critical comments on the manuscript.

\section{LITERATURE CITED}

Chowdhery, H. J.; Giri, G.S.; Pal, G.D.; Pramanik, A. \& Das, A. 2008. Materials for the Flora of Arunachal Pradesh. Vol. 2, Asteraceae - Ceratophyllaceae (Giri, G.S.; Pramanik, A. \& Chowdhery, H. J., eds.). Botanical Survey of India, Kolkata. pp. 177 - 179.

Clarke, C.B. 1883. Buddleia Linn. In: Hooker, J. D. (ed.), The Flora of British India. Vol. IV. L. Reeve\&Co., Kent, London. pp. $81-82$.

Das, A.P. \& Chanda, S. 1987. Flowering Calendar of the Angiospermic Flora of Darjeeling Hills, West Bendal (India). Trans. Bose Res. Inst. 50(4): 99 - 133. 
230 Pollen morphology of some species of Buddleja

Dash, S.S. \& Singh, P. 2017. Flora of Kurung Kumey District. Botanical Survey of India, Kolkata. pp. $275-276$.

Erdtman, G. 1952. Pollen Morphology and Plant Taxonomy. Angiosperms. Almsqvist and Wiksell, Stockholm.

Erdtman, G. 1960. The acetolysis technique: a revised description. Svensk Bot. Tisdkr. 54 : $561-564$.

Kearns, C.A. \& Inouye, D.W. 1993. Techiniques for pollination biologies. Niwot (CO): University Press of Colorado.

Li, Ping-tao \& Leeuwenberg, A. J. M.1996. Buddleja Linnaeus. In: Wu, Z.Y. \& Raven, P.H. (eds.). Flora of China. Vol. 15 (Myrsinaceae through Loganiaceae). Science Press, Beijing, and Missouri Botanical Garden Press, St. Louis. pp. 331 - 339.

Mabberley, D.J., 2017. Mabberley's Plant-book, A Portable Dictionary of Plants, their Classification and Uses. $4^{\text {th }}$ Edition. Cambridge University Press, Cambridge. p. 137.

Maity, D.; Maiti, G.G. \& Chauhan, A.S. 2018. Flora of Kanchenjunga Biosphere Reserve, Sikkim. Botanical Survey of India, Kolkata. pp. 393 - 394.

Mosyakin, S.L. \& Tsymbalyuk Z.M. 2013. Pollen morphology of the southern African tribe Teedieae, an early-branching lineage of crown Scrophulariaceae. Willd. 45: 6575.

Murmu, S. 2016. Buddlejaceae. In: Ranjan, V. et al. (eds.), Flora of West Bengal. Vol. III. Botanical Survey of India, Kolkata. pp. $433-435$.

Norton, J.D. 1966. Testing of plum pollen viability with Tetrazolium salts. Proc. Amer. Soc. Hort. Sci. 89: 132 - 134.

Punt, W. \& Leenhouts, P.W. 1967. Pollen Morphology and Taxonomy in the Loganiaceae, Grana Palyn. 7(2-3): 469 - 516.

Rae, S.J. 2001. Buddlejaceae. In: Springate, L.S. (ed.), Flora of Bhutan. Vol. 2(3). Royal Botanic Garden Edinburgh, Edinburgh. pp. 1078 - 1082.

Santapau, A. \& Henry, A.N. 1973. A dictionary of the flowering plants in India. Publication and Information Directorate, CSIR, New Delhi.

Wilhelm, K. 1910. Die Samenpflanzen. Wien, Leipzig: Deuticke. 